\title{
Studentene lærer om \\ helserisikoer med å \\ jobbe i et hjelperyrke
}

Sykepleierstudentene ved Høgskolen i Molde lærer om helserisikoene det medfører å arbeide med mennesker som lider - og om hvordan de som hjelpere kan bli ivaretatt.

Jeanette Varpen Unhjem

Førsteamanuensis

Sykepleierutdanningen, Avdeling for helse- og sosialfag, Høgskolen i Molde

\begin{tabular}{|l|l|l|l|l|l|l|l|}
\hline Sykepleierstudent & Sykepleierutdanning & Frebygging & Arbeidsmiljø
\end{tabular}

Sykepleien 2020108 (82726) (e-82726)

DOI: 10.4220/Sykepleiens.2020.82726

\section{Hovedbudskap}

Sykepleiere og andre hjelpere risikerer å utvikle sekundærtraumatisering, omsorgstretthet (compassion fatigue) og utbrenthet som konsekvens av belastende arbeid.

Utdanningsinstitusjoner har en viktig rolle i å forebygge slik helserisiko. Artikkelen beskriver forkunnskaper hos sykepleierstudenter og undervisning om sekundærtraumatisering, omsorgstretthet og utbrenthet samt ulike former for ivaretakelse av hjelpere. 
Uansett hvor en sykepleier arbeider, vil sykepleieren møte personer som lider, er i kriser eller har opplevd traumatiske hendelser. En viktig sykepleieroppgave er å møte personene med åpenhet og omsorg. Arbeidet kan oppleves meningsfullt og givende, men det kan også ha negativ innvirkning på sykepleieren. Sykepleiere og andre hjelpere risikerer å utvikle sekundærtraumatisering, omsorgstretthet (compassion fatigue) og utbrenthet som konsekvens av belastende arbeid.

\section{Hvem skal ivareta hjelperne?}

Forebygging er bedre enn behandling når det gjelder helserisiko i hjelperyrker (1). Ansvaret for å ivareta hjelpere er fordelt på tre nivåer: arbeidsgiver, kolleger og individet selv. I tillegg er det en fjerde aktør som er viktig - de som utdanner hjelpere. Isdals, Haavik og Tovens erfaring er at utdanningsstedene i liten grad forbereder studentene på hva arbeidet som hjelper kan gjøre med dem, og hva de kan gjøre med det $(1,2)$.

Artikkelen beskriver et undervisningsopplegg for sykepleierstudenter om helserisikoen ved å arbeide i et hjelperyrke. Jeg presenterer undervisningens pedagogiske oppbygging, studentenes forkunnskaper og faglig innhold.

\section{Slik foregikk undervisningen}

Ved Høgskolen i Molde har de tre siste sykepleierstudentkullene fått undervisning om helserisikoen i hjelperyrker. Undervisningen varte i to timer, og kapittelet Ivaretakelse av hjelperen fra Isdals bok Smittet av vold (1) var pensum.

Undervisningen startet med kartlegging av studentenes forkunnskaper, før det ble gitt en innføring i begrepene sekundærtraumatisering, omsorgstretthet og utbrenthet.

Hoveddelen av undervisningen la vekt på ulike former for ivaretakelse av hjelperen: medarbeiderivaretakelse, hverandreivaretakelse og selvivaretakelse.

Studentaktive pedagogiske metoder inkluderte refleksjon i små studentgrupper (summegrupper) og individuelt. Summegruppene ble brukt til å la studentene snakke om tanker og erfaringer knyttet til medarbeider- og hverandreiveratakelse, mens det var individuell skriftlig refleksjon over selvivaretakelse. 
Studentene ble oppfordret til å dele relevante erfaringer fra kliniske studier og fra eventuelt eget arbeid $\mathrm{i}$ plenumsdiskusjonene.

\section{Studentenes forkunnskaper ble kartlagt}

For å kartlegge sykepleiestudentenes

forkunnskaper utarbeidet jeg et spørreskjema med sju spørsmål med felt for svar i fritekst:

1. Hva er sekundærtraumatisering?

2. Hva er compassion fatigue (omsorgstretthet)?

3. Hva er utbrenthet?

4. Er hjelpere mer utsatt for disse tilstandene enn personer i andre yrker?

5. Er noen hjelpere mer utsatt for disse tilstandene enn andre hjelpere?

6. Hvordan kan disse tilstandene forebygges?

7. Har du kommentarer til temaene eller spørreskjemaet?

Studentene fikk informasjon om at det ikke var forventet at de hadde mye kunnskaper om temaene på forhånd, at spørreskjemaet ikke kunne knyttes til den enkelte student, og at deres svar eller deltakelse ikke ville ha innvirkning på karakterene. I tillegg presiserte jeg at innlevering av skjemaet innebar samtykke til at svarene kunne brukes i rapporter eller forskning, og at det var frivillig å delta i kartleggingen.

Tre kull med sykepleierstudenter deltok i kartleggingen av forkunnskaper. Undervisningen foregikk i andre, fjerde eller femte semester av sykepleierstudiet. De fleste studentene valgte å besvare spørreskjemaet, og den følgende oppsummeringen er basert på data fra 182 utfylte skjemaer.

\section{Få hadde hørt om sekundærtraumatisering}

Studentene hadde lite kjennskap til begrepet sekundærtraumatisering, men noen kjente begrepet eller resonnerte seg frem til at det handlet om å bli traumatisert av andre personers opplevde traumer.

Studentene beskrev dette som «om man som helsepersonell traumatiseres av å høre pasienter fortelle om traumatiske opplevelser» og «hvis pasientene forteller om noe grusomt som de har opplevd, kan det traumatisere sykepleieren». 


\title{
$\equiv$ «Noen kjente begrepet eller resonnerte seg frem til at det handlet om å bli traumatisert av andre personers opplevde traumer.»
}

Noen studenter var tydelige på at sekundærtraumatisering skjer indirekte: «Traume som kommer av at situasjoner og hendelser blir fortalt til sykepleier. Ikke-direkte opplevd, men beskrevet detaljert og kan oppleves sterkt».

Andre studenter forvekslet det med direkte traumer: «Har ikke hørt om det før, men kanskje traumer man kan få etter å ha opplevd fysiske/psykiske traumer».

\section{De var usikre på hva compassion fatigue betyr}

Studentene var usikre på hva begrepet compassion fatigue betydde og viste dette gjennom å skrive sånt som «litt usikker her» eller ved å sette inn spørsmålstegn etter svaret. Noen studenter oversatte begrepet til norsk, medfølelsestretthet, og beskrev det som å være «sliten av å ha så mye medfølelse».

Liknende beskrivelser dukket opp fra flere studenter:

«sykepleier sliter seg ut med å bry seg for mye», «man gir så mye omsorg til andre at man ikke orker lenger å ta inn over seg andre historier og tragedier» og «om du som sykepleier lever deg inn i pasientens situasjon i så stor grad at du blir utslitt av jobben». «Det er vel noe med hva det koster deg som helsepersonell å stå i jobben», skrev en student.

\section{$\equiv$ ¿Ord som tretthet og utmattelse gikk igjen i flere av svarene fra studentene.»}

\begin{abstract}
Compassion fatigue var for flere av studentene knyttet til omkostningene ved å bry seg om og å gi av seg selv til pasientene. Studentene så for seg «at man blir utmattet av å være empatisk og forståelsesfull», og at man kan bli «utmattet/sliten av å være den støttende og medfølende».
\end{abstract}

Andre studenter forklarte det gjennom kunnskaper om fatigue ved å vise til at «mange får fatigue etter alvorlig sykdom, for eksempel etter hjerneslag eller kreftsykdom». Ord som tretthet og utmattelse gikk igjen i flere av svarene fra studentene, og noen foreslo at compassion fatigue var det samme som utbrenthet. 


\section{Studentene kjenner begrepet utbrenthet}

Av de tre begrepene var utbrenthet mest kjent for studentene.

Det var spesielt tre dimensjoner som sto frem i studentenes beskrivelser: at utbrenthet var en konsekvens av overbelastning, at symptomene var fysiske og psykiske, og at det var en prosess som skjer over tid.

Overbelastningen ble beskrevet som å «jobbe seg i hjel», «gått på høygir» og «overprestert». Overbelastningen fører til at sykepleieren «går på veggen», at «kroppen sier til slutt stopp» og at en har «tømt lagrene sine», men ikke klarer å få «ladet batteriene».

\section{三 «Studentene påpekte at utbrenthet var en konsekvens av å stå under høy arbeidsbelastning over tid.»}

Selv om mange studenter nevnte de fysiske signalene og symptomene ved utbrenthet, hadde de også en bevissthet om at utbrenthet har en psykisk dimensjon. I teksten vises dette gjennom at studentene ofte skriver «fysisk og psykisk» sammen, og at energiløsheten som utbrenthet er kjennetegnet ved, viser seg som for eksempel tretthet og manglende motivasjon.

Studentene påpekte at utbrenthet var en konsekvens av å stå under høy arbeidsbelastning over tid - «overbelastet over en lengre tid med stress, arbeid, belastninger».

\section{Noen hjelpere er mer utsatt enn andre}

Studentene knyttet det å være spesielt utsatt til spesifikke helseprofesjoner, blant annet sykepleiere, men påpekte at personer i andre yrker som har høy belastning - mye «press og stress» - også kan være utsatt.

«Mulig yrker som hjelper andre er mer utsatt, men tror alle kan bli overbelastet, uansett jobb, om presset er for høyt over lengre tid», skrev en student. En annen student mente at «de som jobber i institusjoner hvor det er høyt arbeidspress, lite bemanning, altfor mange oppgaver» var spesielt utsatt.

Noen studenter antydet at det å arbeide med utsatte og sårbare pasientgrupper med traumer kunne gjøre hjelpere mer utsatt. 


\section{$\equiv$ «Individuell sårbarhet og evne til å sette grenser og skille mellom jobb og fritid ble også fremhevet.»}

Individuell sårbarhet og evne til å sette grenser og skille mellom jobb og fritid ble også fremhevet.

En student pekte på: «de som er mer sårbar og ikke takler stress, og som jobber mye og ikke spør om hjelp». «Man kommer veldig tett på mennesker og må gi mye av seg selv, så dersom man ikke har en god evne til å skille mellom arbeidsog privatliv er man nok disponert», skrev en annen student. Omsorgsarbeid som krever at man gir mye av seg selv, kombinert med en individuell sårbarhet, kunne dermed gjøre noen hjelpere særlig utsatt for helserisiko.

\section{Hva sier studentene om forebygging?}

Ifølge studentene, kunne forebygging skje gjennom tiltak på individ-, kollega- og ledernivå. Forebyggende tiltak på individnivå var for eksempel å «kjenne seg selv», «være fysisk aktiv, ved å være sunn og bevisst på det i alle aspekt, ved å stadig videreutvikle seg ved å stadig lære mer» og «ta tid til seg selv, be om hjelp».

\section{三 «Muligheten til å få snakke ut om vanskelige hendelser, ble fremhevet som et viktig forebyggende tiltak.»}

Et «godt arbeidsmiljø» var sentralt i forebyggingen, skrev mange studenter. Muligheten til å få snakke ut om vanskelige hendelser ble fremhevet som et viktig forebyggende tiltak. Samtaler med kolleger var én mulighet, men profesjonell veiledning, for eksempel med psykolog, ble også nevnt. Flere studenter så dette som et ansvar for ledere og arbeidsgivere.

Ledere og arbeidsgivere ble ansett som ansvarlige for å tilrettelegge for tilpasset turnus, tilpasset arbeidsmengde og å sørge for at det var god nok bemanning. $\varnothing \mathrm{kt}$ bemanning ble trukket frem av mange studenter. «Mer arbeidskraft», «nok folk i arbeid», «flere arbeidere» og «mer bemanning» var beskrivelser som gikk igjen.

I tillegg presiserte studentene at opplæring, undervisning og kurs kunne bidra til å få kompetanse i hvordan de kunne ta vare på seg selv og sine medarbeidere. 
I siste del av spørreskjemaet var det spesielt to kommentarer som gikk igjen: at studentene var usikre på begrepene, og at de mente det var viktige temaer å lære om.

\section{Presentasjon av undervisningstemaene}

Boken Smittet av vold (1) var utgangspunktet for undervisningen. I den følgende presentasjonen av undervisningstemaene supplerer jeg med flere relevante kilder.

\section{Hjelpere kan bli sekundærtraumatiserte}

Posttraumatiske stressymptomer er en helserisiko for hjelpere som blir utsatt for vold eller andre overveldende hendelser på jobb (1). Symptombildet omfatter blant annet indre uro, flashbacks, mareritt, følelsessvingninger, unngåelse, konsentrasjons- og hukommelsesvansker, hodepine, muskelspenninger og søvnvansker (1).

Sekundærtraumatisering handler om at hjelpere som møter traumatiserte personer og mottar historiene deres, vil kunne få noen av de samme reaksjonene som den traumatiserte selv (1).

For hjelperne vil reaksjonene sjelden være like sterke som hos dem som opplevde katastrofene eller traumene, men reaksjonene kan bygge seg opp over tid etter hvert som hjelperen møter flere traumatiserte personer (1).

Hjelpere som lytter til traumatiserte personers fortellinger, opplever hendelsen indirekte gjennom det personen forteller (3). Hjelperne har ikke selv vært eksponert for den traumatiske hendelsen eller de første reaksjonene, men de kan forestille seg hva som skjedde, og de kan bevitne både fysiske og psykiske konsekvenser for den traumatiserte personen (3).

På den positive siden, kan de også i noen tilfeller bevitne overlevelsesevne, mot, håp, vilje og kamp for å komme seg videre i livet (3). 
Sekundærtraumatisering er en normal reaksjon på å ha blitt påvirket av møter med traumatiserte personer over tid (3). «Det er ikke et spørsmål om å bli berørt, men når og på hvilken måte man blir det», skriver Haavik og Toven (2).

Det er ikke nødvendig å ha blitt eksponert for mange personer med traumatiske historier, sekundærtraumatisering kan oppstå etter ett enkelt tilfelle (2).

Risikoen for at hjelperen utvikler egne symptomer, er likevel større over tid, og hvis man må forholde seg til mange traumatiserte personer samtidig uten tilstrekkelig tid til å hente seg selv inn igjen (2).

\section{Omsorgstretthet kan utvikle seg over tid}

«Compassion fatigue er noe som utvikler seg over gjentatte møter med lidelse», skriver Isdal (1). En norsk variant av begrepet er omsorgstretthet og kjennetegnes ved at hjelperen blir distansert, kynisk og nummen (2). Symptomene kan forkle seg som den late, vanskelige, krevende, arrogante eller klagete kollegaen (1), mens hjelperen selv kan oppleve blant annet liten tro på at jobben de gjør utgjør en forskjell, vegring for enkelte arbeidsoppgaver, synkende motivasjon og følelsesavflating (1).

På liknende måte som ved sekundærtraumatisering, kan compassion fatigue være en konsekvens av å lytte til eller støtte pasienter som har vært utsatt for traumatiske hendelser, men det kan også være en følge av å være utsatt for andres lidelser over tid - uten at det er snakk om traumer (4).

\section{Karakteristiske trekk ved utbrenthet}

Begrepet utbrenthet har over flere tiår blitt definert og forstått på mange måter (5). Spesielt karakteristiske trekk ved utbrenthet er den følelsesmessige utmattelsen, den depressive karakteren til symptomene og plagene, og at utbrenthet utvikler seg over tid (5). I Norsk helseinformatikks (6) definisjon poengteres det at utbrenthet er en normal stressreaksjon, som vanligvis gir både psykiske og fysiske plager. 
Utbrenthet er knyttet til forhold på arbeidsplassen (3). Skovholt og Trotter-Mathison (4) har identifisert sju faktorer som kan forårsake utbrenthet: for stor arbeidsmengde, mangel på kontroll og innflytelse, manglende feedback og anerkjennelse, manglende arbeidsfellesskap, urettferdighet, verdikonflikter og manglende kompetanse til å utføre arbeidsoppgavene.

\section{Hvordan kan hjelperen bli ivaretatt?}

Medarbeiderivaretakelse ligger til arbeidsgivers ansvar (2). Arbeidsgiver er lovpålagt å sørge for gode arbeidsforhold. Arbeidsmiljølovens (7) formål er blant annet å sikre trygghet mot fysiske og psykiske skadevirkninger og legge til rette for tilpasninger i arbeidsforholdet knyttet til den enkelte arbeidstakers forutsetninger og livssituasjon.

Når det gjelder helsefarer i relasjonsintensive yrker, skriver Haavik og Toven (2) at deres inntrykk fra mange års kursvirksomhet, er at en del hjelpere får opplæring i hvordan de kan beskytte seg mot vold, men at det sjelden er opplæring i hvordan de kan forebygge sekundærtraumatisering og omsorgstretthet.

Isdal (1) skisserer seks grunnfaktorer i arbeidsforholdene som virker inn på ansattes helse: sikkerhet, arbeidsmengde, kompetanse, anerkjennelse, medinnflytelse og meningsfullhet.

\section{$\equiv$ «Hverandreivaretakelse handler om støtte fra og trygghet i gode kolleger.»}

Hverandreivaretakelse handler om støtte fra og trygghet i gode kolleger (1). «Et godt kollegafellesskap $\varnothing$ ker både motivasjonen og evnen til å håndtere krevende mellommenneskelige situasjoner», ifølge Haavik og Toven (2).

Hverandreivaretakelse omfatter mange elementer, men noen sentrale kan være: felles møtepunkter, «bli kjent»-prosesser, interesse for hverandre, felles ansvarsfølelse, unngå klagekultur, fordeling av belastninger, omsorg og inkludering av nyansatte, kultur med positive tilbakemeldinger og hyggepunkter (1). 
Mye av litteraturen om forebygging handler om hva den enkelte hjelper kan gjøre for å ta vare på sin egen helse (1). Dette omfatter fysisk, psykisk og emosjonell helse, og selvivaretakelse rommer mange ulike forebyggende tiltak.

Isdal (1) peker på ti punkter som han ser som sentrale i selvivaretakelse. Punktene dekker blant annet viktigheten av restitusjon og profesjonell selvivaretakelse, og Isdal gir konkrete eksempler på tiltak - som fysisk trening, mye hvile, selvrefleksjon, be om hjelp og forhandle om arbeidsforhold. Tiltakene kan ses på som «personlig verneutstyr» som beskytter hjelperen mot skader (2).

\section{Konklusjon}

Kartleggingen av sykepleierstudentenes forkunnskaper viste at studentene har begrenset kunnskap om noen betydelige helserisikoer i hjelperyrker, men at de samtidig har klare tanker om hvilke faktorer som er viktige for forebygging.

Studentene så at de som kommende sykepleiere kan være spesielt utsatt for helserisiko som følge av krevende arbeidsforhold - både på grunn av organisatoriske forhold som turnus og arbeidspress, men også på grunn av møtene med lidende og traumatiserte pasienter. Dette understreker behovet for å bidra til forebygging av helserisiko gjennom studentivaretakelse i utdanningsinstitusjonene.

\section{Referanser}

1. Isdal P. Smittet av vold: om sekundærtraumatisering, compassion fatigue og utbrenthet i hjelperyrkene. Bergen: Fagbokforlaget; 2017.

2. Haavik M, Toven S. Ivaretakelse av hjelpere: er vi ikke betalt for å tåle dette? Oslo: Universitetsforlaget; 2020.

3. Bang S, Nilsen L. Rørt, rammet og rystet: faglig vekst gjennom veiledning. Oslo: Gyldendal akademisk; 2003.

4. Skovholt TM, Trotter-Mathison MJ. The resilient practitioner: burnout and compassion fatigue prevention and self-care strategies for the helping professions. 3. utg. England: Routledge; 2016.

5. Roness A, Matthiesen SB. Utbrent: krevende jobber gode liv. Bergen: Fagbokforlaget; 2002. 
6. Norsk Helseinformatikk. Utbrenthet. 2020. Tilgjengelig fra: https://nhi.no/livsstil/egenomsorg/utbrenthet/ (nedlastet 30.10.20).

7. Lov 17. juni $2005 \mathrm{nr} .62 \mathrm{om}$ arbeidsmiljø, arbeidstid og stillingsvern mv. (arbeidsmiljøloven). Tilgjengelig

fra: https://lovdata.no/dokument/NL/lov/2005-06-17-62 (nedlastet 26.05.2020). 